\title{
Finite element modeling of tool stresses on ceramic tools in hard turning
}

\author{
M. Günay*, M. E. Korkmaz**, N. Yaşar**** \\ *Karabük University, Engineering Faculty, 100.Yul, 78050, Turkey, E-mail: mgunay@karabuk.edu.tr \\ **Karabük University, Engineering Faculty, 100.Yll,78050, Turkey, E-mail: merdikorkmaz@karabuk.edu.tr \\ ***Karabük University, TOBB Vocational High School, 100.Yll, 78050, Turkey, E-mail: nafizyasar@karabuk.edu.tr \\ cross $^{\text {ref }}$ http://dx.doi.org/10.5755/j01.mech.23.3.14363
}

\section{Introduction}

Manufacturing of hardened steel parts with high accuracy and surface quality is widely provided by grinding. Hard machining has been suggested to partially replace grinding owing to the relatively high cost of the grinding process. Flexibility and positive ecological effects are other advantages of dry hard machining [1]. Additionally, the surfaces by hard turning may have a longer fatigue life when compared with grinding parts [2].

Recently, machining of hardened steel is a subject of concern for industrial fabrication and scientific investigation as it presents a number of probable advantages, involving high accuracy, lower tooling costs, shorter setup time, less process step, flexibility of larger part geometry, and generally the usage of cutting fluid is unrequired during turning of hardened steel. Manufacturing costs are expected to be reduced by up to $30 \%$ once hard turning is used for producing complex parts [3]. Besides, the main concerns of hard turning are the tool materials cost and the effect of the cutting conditions on machinability characteristics. The machining of hardened steels using cubic boron nitride, polycrystalline cubic boron nitride and ceramic tools is commonly known as a best replacement instead of grinding cost in order to reduce the tooling time and keep off the lubrication [4]. On the other hand, Bensouilah et al. [5] mentioned about optimization of cutting conditions to decrease the cost in mass production. For this purpose, authors performed an optimization study in hard turning of AISI D3 tool steel with coated and uncoated mixed ceramic tools by using the response surface method. The results show that the uncoated ceramic tool is suitable in decreasing the cutting forces strongly influenced by the depth of cut. A lot of investigations have been performed to research the performance of carbide and ceramics tools in the machining of several hardened materials due to higher cost of cubic boron nitride. $\mathrm{Ku}-$ mar et al. [6] observed that the performance of the Ti(C,N) mixed ceramic insert material is better than that of zirconia toughened alumina ceramic insert with respect to machined surface of hardened steel. Gaitonde et al. [7] investigated the influences of depth of cut and machining time on cutting force, power, tool wear and surface roughness have been determined by hard turning of high chromium AISI D2 tool steel with ceramic inserts in different quality. According to experimental results, the cutting force and power increased and tool wear decreased by increasing depth of cut. Karpuschewski et al. [8] observed that combination of the preparation of cutting edge and coating has a significantly decreasing influence on friction force in scratch test. Hence, the authors emphasized that the change of microhardness of coated and uncoated ceramics is insignificant. In finish hard machining with coated ceramic tools, Sokovic et al. [9] analyzed the cutting performance of different coatings of deposited by PVD and CVD techniques on $\mathrm{Al}_{2} \mathrm{O}_{3} / \mathrm{SiC}_{\mathrm{w}}$ ceramic tools. It was shown an indirect relationship between the coating types and machining results. The smallest flank wear was obtained with insert of two layers coating, however the best surface quality was created with multilayer coating. Bhattacharya et al. [10] studied on cutting performance of surface modified $\mathrm{Al}_{2} \mathrm{O}_{3} /$ TiOC mixed ceramic cutting tools. The authors has modified the inserts by posttreatment under argon/ $\mathrm{CO}_{2}$ atmosphere to form a TiN layer with a thickness of $1-1.5 \mu \mathrm{m}$. It was proved that the surface modified tools have higher performance with $29 \%$ than sintered tools in respect of wear rate. Aslantas et al. [11] focused on the continuous hard turning of AISI 52100 steel using coated and uncoated $\mathrm{Al}_{2} \mathrm{O}_{3}-\mathrm{TiCN}$ ceramic tools cheaper than $\mathrm{CBN}$ or PCBN. Authors noticed from the results that the damage types of fracture and chipping arise more commonly in uncoated tools while the most common type of damage is crater wear in TiN coated tools. The most significant result acquired from this study is that the chip flow direction is affected from TiN coating and crater wear. Shalaby et al. [12] studied on the performance of PCBN, TiN coated PCBN and mixed ceramic inserts in hard turning of AISI D2 steel. The results showed that ceramic inserts have created longer tool life and less cutting forces than PCBN tool, which can be referred to its higher chemical and thermal stability.

Experimental methods have many difficulties in the cutting process for analysis of machinability characteristics, namely, cutting force, temperature, strain, strain rate, and stress. Thus, the finite element models predicting these characteristics have been performed to increase the production capacity by uncompromising their required values. The techniques such as finite element method, regression analysis and artificial neural network etc. are used. Finite element method is the most commonly used among these techniques in order to forecast the machining characteristics. Many modelling research have been studied for the performance of different tool grades in cutting process of several materials. Yan et al. [13] investigated the influences of strain, strain rate and temperature on flow stress in hard turning of AISI H13 tool steel. It is claimed that the determination of mechanical behavior of flow stresses is very difficult in hard turning and so this problem should be solved with finite element method. Authors emphasized the validity of finite element model with DEFORM 2D when compared with experimental data. Umbrello et al. [14] studied on flow stresses depending on hardness for numerical simulation during hard turning of AISI H13 in different cutting speed and depth of 
cut. It was found that cutting tool stresses decrease by increasing cutting speed, but the stresses increase with increasing material hardness. It was noticed that the results are very similar while comparing of data taken from experiments and finite element analysis with DEFORM. Özel [15] investigated the effects of cutting tool geometries on cutting force, stress and tool wear in hard turning of AISI 4340 with PCBN cutting tool and then developed a model with 3D finite element method. It was observed that variable edged insert is more useful than that of uniform edged. These inserts provide longer tool life and less consumption of power. It was proved that the finite element model with DEFORM 3D and experimental results are very similar and so the model has high validity. Kurt et al. [16] developed a finite element model for determining the tool stresses in hard turning of AISI H13 with ceramic tools. The results show that cutting tool stresses decrease with increasing depth of cut. Also, the authors emphasized that the areas of stress concentration in FEA provide information about probable tool wear type once finish turning has been continued. Thus, it is deduced that the probable crater wear may arise at the tip of toolchip contact area owing to high compression stresses once finish turning has been continued.

There is a little if any studies on modelling of cutting tool stresses in hard turning although there is a lot of studies on hard turning as can be understood from mentioned literature. In this study, the changes of cutting forces depending on cutting conditions (cutting speed, depth of cut and feed rate) has been investigated during the machining of DIN 1.2344 tool steel $(55 \pm 1$ HRC) with uncoated ceramic inserts. Finally, the stresses distribution on cutting tools were analyzed based on finite element method by using ANSYS.

\section{Material and method}

\subsection{Experimental procedure}

The purpose of this study was investigating the effects of cutting parameters on cutting forces and cutting tool stresses in hard turning of DIN 1.2344 steel using uncoated ceramic tools. The experiments were carried out using a Johnford TC35 CNC lathe controlled by Fanuc with 20 HP spindle power. The following cutting conditions were used for the experiments: cutting depth $(a)$ of $0.1,0.2$ and 0.3 $\mathrm{mm}$, feed rate $(f)$ of $0.05,0.10$ and $0.15 \mathrm{~mm} / \mathrm{rev}$ and cutting speed $(V)$ of 90,120 and $150 \mathrm{~m} / \mathrm{min}$. However, cutting force components (main cutting force, feed force and radial force) were also added as cutting parameters in order to analyze cutting tool stress. The workpiece material has the following chemical composition: $0.4 \% \mathrm{C}, 1.0 \% \mathrm{Si}, 0.40 \% \mathrm{Mn}, 5.1 \%$ $\mathrm{Cr}, 1.3 \% \mathrm{Mo}, 1.0 \% \mathrm{~V}$ and the balance is Fe. The workpiece was hardened to $55 \pm 1$ HRC by means of heat treatment by quenching in a vacuum atmosphere.

Ceramic inserts with $0.4 \mathrm{~mm}$ tool nose radius (DNGA 150404 T02020) were used to machining of DIN 1.2344 tool steel. The cutting tool was fixed to tool holder which has ISO code of DDJNR 2525M15. Combination of the cutting tool and the tool holder resulted in effective rake angle $\gamma=-26^{\circ}$, clearance angle $\alpha=-6^{\circ}$, inclination angle $\lambda=-6^{\circ}$ and approaching angle $\chi_{r}=93^{\circ}$. The workpiece was clamped into the machine to minimize run-out and maximize rigidity. The measurement of the cutting forces was done by the Kistler piezoelectric dynamometer type 9257B which was connected to a Kistler 5070A of multi-channel charge amplifier. The measured values were continuously monitored and recorded throughout the Dynoware software.

\subsection{FEA for the cutting tools}

The finite element analyses of the tool stress were performed with ANSYS Workbench software depending on finite element method. The preparations required for the analyses has following order: 3D model of the cutting tools and tool holder, defining of materials property requisite for cutting tools, elements types and its size, model meshing, designation of boundary and loading conditions selecting of solution methodology. These preparations are given in Fig. 1.

The prepared solid models were imported to ANSYS Workbench after the cutting tools are modelled via SolidWorks. Besides, the tool-chip contact area was determined in modeling of the cutting tools based on Zorev approach [17] and applied as in the Ref. [19]. The tool-chip contact length presented in Fig. 2 is calculated as follow [18]:

$$
\begin{aligned}
& l_{c}=2 \lambda a, \\
& \lambda=a_{1} / a,
\end{aligned}
$$

where $l_{c}, a, \lambda$ and $a_{1}$ are the tool-chip contact length, the undeformed chip thickness or depth of cut, the coefficient of chip thickness and the chip thickness, respectively. According to Toropov and Ko with Eq. (1), the tool-chip contact areas (Fig. 1) with $l_{c}=0.38,0.76,1.14 \mathrm{~mm}$ were measured as $0.0841,0.2893$ and $0.5764 \mathrm{~mm}^{2}$ on tool rake face for depth of cut $a=0.1,0.2,0.3 \mathrm{~mm}$, respectively.

Furthermore, some details for the tool holder were created like small edge chamfering/rounding on tool holder and the fastening parts, and also parts of tool holder in the dynamometer were ignored to reduce elements number and time of calculation in modelling of finite element method (FEM). The tool holder was modelled depending on actual clamping length which is $25 \mathrm{~mm}$ in turning. The properties of material such as elasticity modulus $(E)$ and Poisson's ratio ( $v$ ) used as Ref. [19] in modelling of cutting tools are used for linear elastic material models (Table 1). Moreover, C3D10 (10-node quadratic tetrahedral element) was used as the element type for the cutting tools in the FEM. The meshing was performed by considering the default values suggested from ANSYS Workbench. The meshes were applied to the tool-chip contact area on insert rake face densely and to the rest rarely (Fig. 3, a). Consequently, the total 31179 nodes were used while 17641 elements were used for these cutting tools in the analysis, respectively. The behaviour of contact surfaces should be considered in FEM, although the contacts in the model were automatically perceived. Then, the contact surfaces are bonded symmetrically in all directions. Hence, the additional force for clamping the insert with the tool holder is not required. The designation of the boundary and loading conditions is the final preparation step before the solution for FEM. For this purpose, the cutting force components $\left(F_{c}, F_{f}, F_{r}\right)$ affecting on the insert are applied to the tool-chip contact area depending on the following processes: The main cutting force $\left(F_{c}\right)$ was implemented to tool-chip contact area as triangular variable load. Here, the $F_{c}$ value is zero at the tip of the tool-chip contact area 
based on coordinate system origin illustrated in Fig. 3, b. Besides, the highest $F_{c}$ value at first contact point between the insert and chip at distance $l_{c}$ in $\mathrm{Z}$ direction is shown in Fig. 3, b. However, the radial force $\left(F_{r}\right)$ and feed force $\left(F_{f}\right)$ have been applied normally to the tool-chip contact area in
$\mathrm{X}$ and $\mathrm{Y}$ directions whose are radial and feed motion of cutting tool, respectively. The weights of the cutting tools, the vibration and temperature occurred in hard machining were ignored in FEA to diminish the time of calculation in the analysis.

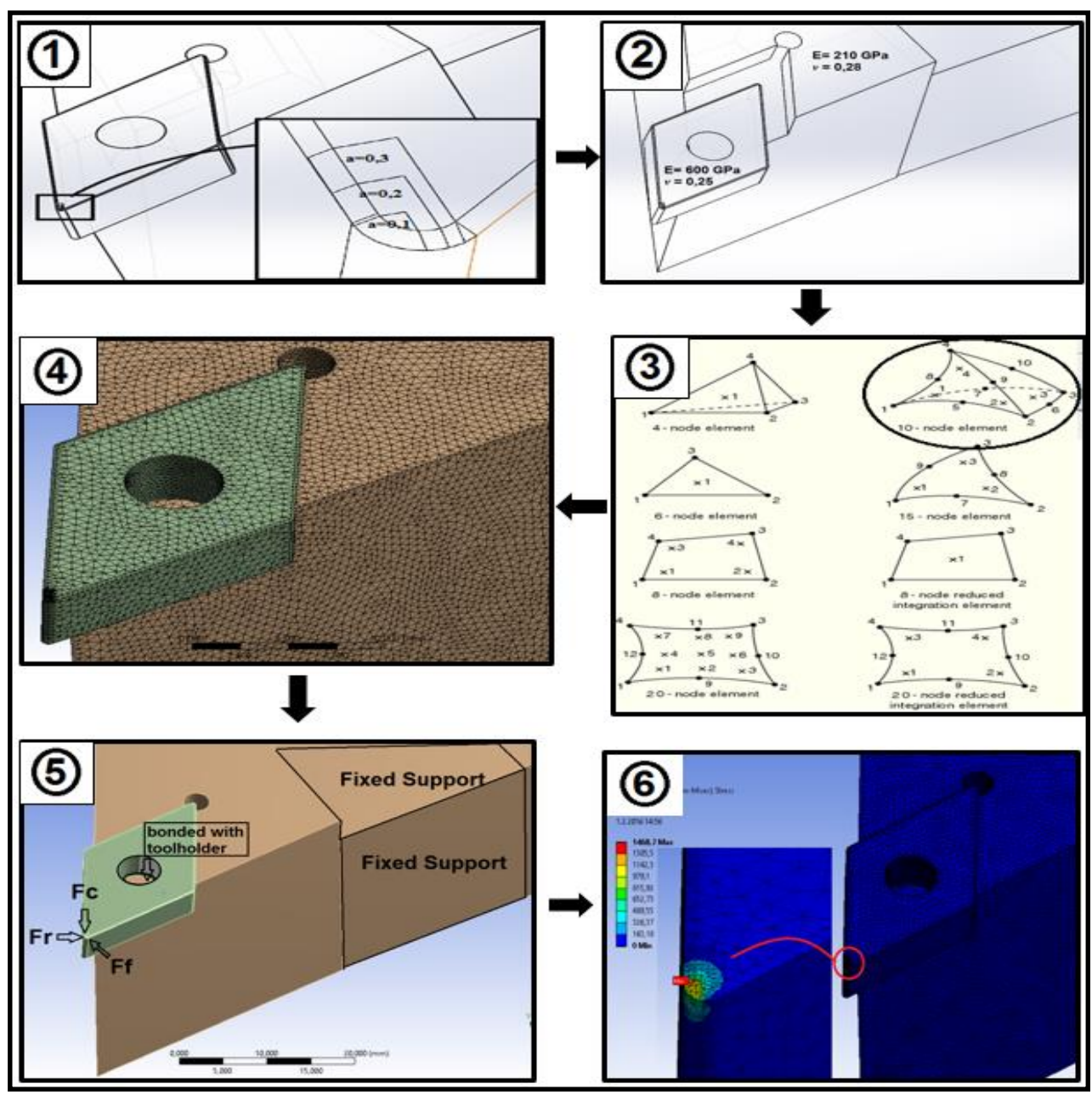

Fig. 1 Stages of finite element analysis

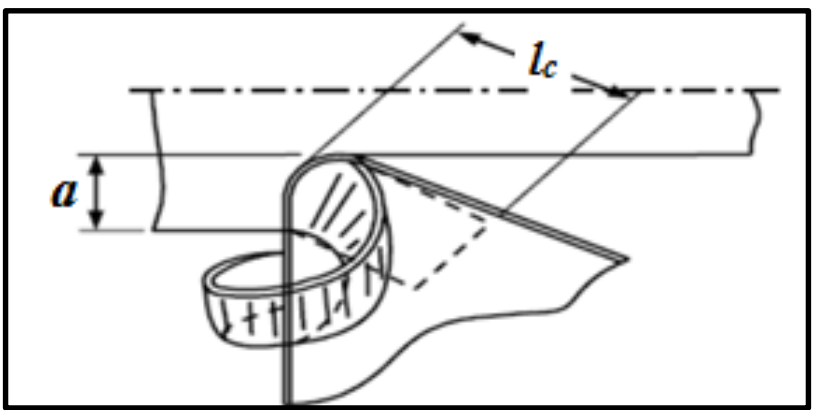

Fig. 2 Tool-chip contact length

Table 1

The material properties of cutting tool and tool holder [20]

\begin{tabular}{|c|c|c|}
\hline Cutting tools & $E, \mathrm{GPa}$ & $v$ \\
\hline Tool holder & 210 & 0.28 \\
\hline Uncoated ceramic insert & 600 & 0.25 \\
\hline
\end{tabular}




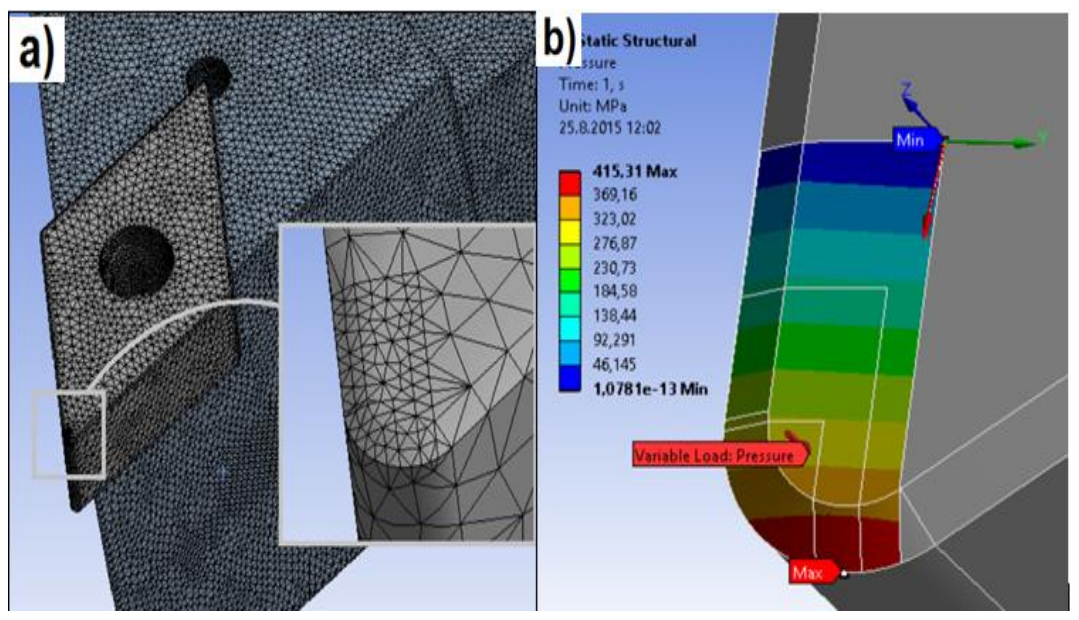

Fig. 3 a) Mesh structure, b) Loading of $F_{c}(a=0.3 \mathrm{~mm}, f=0.15 \mathrm{~mm} / \mathrm{rev}, V=90 \mathrm{~m} / \mathrm{min})$

Finally, FEM solutions have been done by ANSYS Workbench software as nonlinear because of contact surfaces between cutting insert and tool holder. The converge criterion controls the relation between force and displacement with Full Newton-Raphson method in each iterative solution step in the FEA. Wear zone or wear type on cutting tool may be forecasted according to distributions of cutting tool stresses. Therefore, the results of cutting tool stresses were examined for the detection of possible wear zone of the insert according to the cutting conditions.

\section{Results and discussion}

\subsection{Analyses of cutting forces}

The most important factor with respect of energy consumption is the main cutting force in turning processes. However, the magnitude order of cutting force components can change due to especially tool geometry, cutting parameters and material hardness in hard turning. Therefore, three dimensional cutting force components should be considered for the analysis of cutting forces in respect of cutting tool stresses, which affect the tool wear indirectly. The change of $F_{f}, F_{r}$ and $F_{c}$ values obtained with three different cutting depth, feed and cutting speed was given in Fig 4.

It is known that tool material is an important factor affecting chip formation and then cutting forces positively or negatively. Therefore, the influences of cutting parameters with ceramic insert on cutting forces components were assessed by means of the figures. In general, $F_{c}$ was measured as the highest force component, following radial and feed force in the same cutting conditions. The increasing depth of cut causes the reduction of squeezed material phenomena and to the domination of the main cutting force as mentioned by Meddour et.al [4]. It was determined that all cutting force values increased with increasing feed rate and depth of cut. The result also observed that cutting speed has inconsiderable effect on cutting force components as mentioned in Ref. [20]. As seen also from Fig. 4, there is a little decrease on the forces from 120 to $150 \mathrm{~m} / \mathrm{min}$ of cutting speed [20]. The highest and lowest values of all force components have been obtained in the $21^{\text {st }}$ and $7^{\text {th }}$ experiments, respectively. The highest values for feed, radial and main cutting forces were calculated as 96.39, 120.99 and $206.59 \mathrm{~N}$, respectively for $90 \mathrm{~m} / \mathrm{min}$ cutting speed, $0.15 \mathrm{~mm} / \mathrm{rev}$ feed rate and $0.3 \mathrm{~mm}$ depth of cut. The lowest values were calculated as $19.88,33.57$ and $54.59 \mathrm{~N}$, respectively for $150 \mathrm{~m} / \mathrm{min}$ cutting speed, $0.05 \mathrm{~mm} / \mathrm{rev}$ feed rate and $0.1 \mathrm{~mm}$ depth of cut.

Additionally, analysis of variance (ANOVA) results performed on the $95 \%$ confidence level to determine the influence of factors on cutting force components are given in Table 2-4. Here, the probability $(P)$ values indicating the importance level of each factor, degree of freedom (DoF), the sum of squares (SS), mean square (MS), $F$ values and the percent contribution ratio $(P C R)$ is shown. $P$ value should be lower than 0.05 in $95 \%$ confidence level in order to determine that any factor acting on the force is effective on it. It is shown that the most effective factor on feed force and main cutting force is depth of cut with $82.66 \%, 51.35 \%$, respectively as seen from Table $2-4$. The feed rate has become the most important factor on radial forces with $50.10 \%$ PCR. It is also shown from Table 2-4 that cutting speed has a little impact on feed force and radial force while it has insignificant impact on main cutting force in these cutting conditions.

Table 2

Analysis of variance (ANOVA) results for $F_{f}$

\begin{tabular}{|c|c|c|c|c|c|c|}
\hline Factor & $\begin{array}{c}\text { Degree } \\
\text { of free- } \\
\text { dom }\end{array}$ & $\begin{array}{c}\text { Sum of } \\
\text { square }\end{array}$ & $\begin{array}{c}\text { Mean } \\
\text { square }\end{array}$ & $\begin{array}{c}F \\
\text { value }\end{array}$ & $\begin{array}{c}P \\
\text { value }\end{array}$ & $\begin{array}{c}P C R \\
(\%)\end{array}$ \\
\hline$V$ & 2 & 313.6 & 156.79 & 4.82 & 0.020 & 2.18 \\
\hline$f$ & 2 & 1521 & 760.51 & 23.37 & 0.000 & 10.61 \\
\hline$a$ & 2 & 11846 & 5922.9 & 181.9 & 0.000 & 82.66 \\
\hline Error & 20 & 651 & 32.55 & & & 4.55 \\
\hline Total & 26 & 14331 & & & & 100.0 \\
\hline
\end{tabular}

Table 3

Analysis of variance (ANOVA) results for $F_{r}$

\begin{tabular}{|c|c|c|c|c|c|c|}
\hline Factor & $\begin{array}{c}\text { Degree } \\
\text { of free- } \\
\text { dom }\end{array}$ & $\begin{array}{c}\text { Sum of } \\
\text { square }\end{array}$ & $\begin{array}{c}\text { Mean } \\
\text { square }\end{array}$ & $\begin{array}{c}F \\
\text { value }\end{array}$ & $\begin{array}{c}P \\
\text { value }\end{array}$ & $\begin{array}{c}P C R \\
(\%)\end{array}$ \\
\hline$V$ & 2 & 503.7 & 251.85 & 6.83 & 0.005 & 3.44 \\
\hline$f$ & 2 & 7338.9 & 3669.4 & 99.57 & 0.000 & 50.10 \\
\hline$a$ & 2 & 6069.1 & 3034.5 & 82.35 & 0.000 & 41.43 \\
\hline Error & 20 & 737 & 36.85 & & & 5.03 \\
\hline Total & 26 & 14648 & & & & 100.0 \\
\hline
\end{tabular}




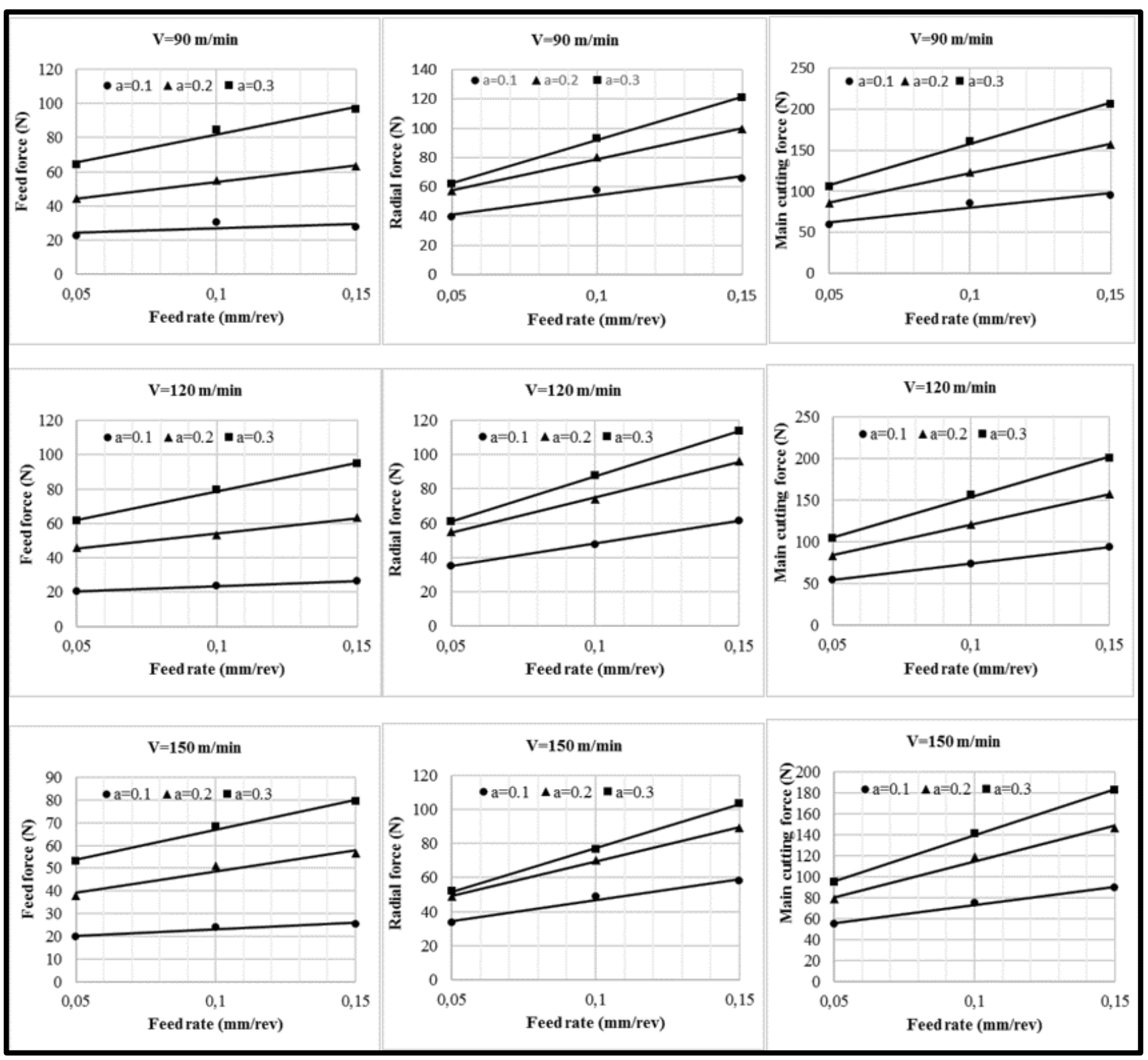

Fig. 4 Cutting forces versus cutting parameters

Table 4 normal stress in x-direction $\left(\sigma_{x}\right)$, normal stress in y-direction

Analysis of variance (ANOVA) results for $F_{c}$

\begin{tabular}{|c|c|c|c|c|c|c|}
\hline Factor & $\begin{array}{c}\text { Degree } \\
\text { of free- } \\
\text { dom }\end{array}$ & $\begin{array}{c}\text { Sum of } \\
\text { square }\end{array}$ & $\begin{array}{c}\text { Mean } \\
\text { square }\end{array}$ & $\begin{array}{c}F \\
\text { value }\end{array}$ & $\begin{array}{c}P \\
\text { value }\end{array}$ & $\begin{array}{c}P C R \\
(\%)\end{array}$ \\
\hline$V$ & 2 & 533.8 & 266.9 & 174 & 0.185 & 1.08 \\
\hline$f$ & 2 & 20656 & 10328 & 71.09 & 0.000 & 41.70 \\
\hline$a$ & 2 & 25436 & 12718 & 87.54 & 0.000 & 51.35 \\
\hline Error & 20 & 2905.7 & 145.3 & & & 5.87 \\
\hline Total & 26 & 49531 & & & & 100.0 \\
\hline
\end{tabular}

\subsection{Analyses of cutting tool stresses}

Finite element analyses were done by using cutting forces obtained in the experiments. Cutting tool stresses were examined for different levels in depth of cut, feed rate and cutting speed. The critical zone in terms of the cutting tool wear is specified as being equal to the depth of cut on the main cutting edge of the cutting insert for this cutting condition (Fig. 5, e). The variations of cutting tool stress, $\left(\sigma_{y}\right)$, normal stress in z-direction $\left(\sigma_{z}\right)$, shear stress in xyplane $\left(\tau_{x y}\right)$ and von Mises or equivalent stress $\left(\sigma_{e}\right)$ is given in Fig. 5.

Generally, tensile normal stresses $(\sigma)$ in 3-D has insignificant variation regardless of cutting speed, feed rate and depth of cut for all cutting conditions. This is because the all cutting force components apply compression force to the cutting tool. Thus, only compressive stresses were active and evaluated in this study. It is shown from Fig. 6 that all cutting tool stresses decreased by increasing cutting speed, but increased by increasing feed rate. The depth of cut has increasing effect on cutting tool stresses except of the stresses on $\mathrm{x}$-direction. The stresses on $\mathrm{x}$-direction has no specific increase or decrease based on depth of cut. The reason for this variation in tool stress can be attributed that squeezed material cause increase in probable tool vibration. It is also seen from Fig. 6 that the other stresses generally increased about two times when the depth of cut increased from 0.1 to $0.2 \mathrm{~mm}$. However, a little increase in stresses can been seen once the depth of cut increased from 0.2 to $0.3 \mathrm{~mm}$. This situation can be referred to the variation of 
chamfered area on cutting tool based on depth of cut. This is because the increasing ratio of the area decreased with increasing depth of cut from 0.1 to $0.3 \mathrm{~mm}$. Moreover, cutting tool stresses increased by increasing feed rate because toolchip contact area has no change with increasing feed rate which has increasing effect on force components. For all depth of cut values, the tool stresses decreased about $10 \%$, $15 \%$ and $12 \%$ with increasing of cutting speed from 90 to $150 \mathrm{~m} / \mathrm{min}$ in $0.05,0.1$ and $0.15 \mathrm{~mm} / \mathrm{rev}$ of feed rate, respectively. This can be attributed that the chip formation and chip flow is easier on the tool-chip contact area because of decreasing friction coefficient in tool-chip interface and thereby cutting forces decrease by increasing of cutting speed during hard turning. The highest value of compressive normal stress in $\mathrm{x}$-direction $\left(\sigma_{x}\right)$ is $2061.9 \mathrm{MPa}$, in $\mathrm{y}$-direction $\left(\sigma_{y}\right)$ is $1795.7 \mathrm{MPa}$ and in $\mathrm{z}$-direction $\left(\sigma_{z}\right)$ is $1401.7 \mathrm{MPa}$ for $90 \mathrm{~m} / \mathrm{min}$ of cutting speed, $0.15 \mathrm{~mm} / \mathrm{rev}$ of feed rate and $0.3 \mathrm{~mm}$ depth of cut. The highest shear stress on xy-plane $\left(\tau_{x y}\right)$ and highest von Mises stress $\left(\sigma_{e}\right)$ is 1428.9 and $3158.4 \mathrm{MPa}$, respectively for also the same cutting conditions.

Cutting tool stresses is achieved by using cutting forces in hard machining of DIN 1.2344 tool steel with uncoated ceramic cutting tool. It is mentioned that wear zone on cutting tool may be predicted according to von Mises stress distributions [21]. In this regard, stress analysis results performed on ANSYS is shown in Fig. 7, b. In addition, tool image (Fig. 7, a) is taken from Nikon SMZ745T microscope in order to demonstrate the consistency of ANSYS results and locate the possible wear zone on cutting tool.

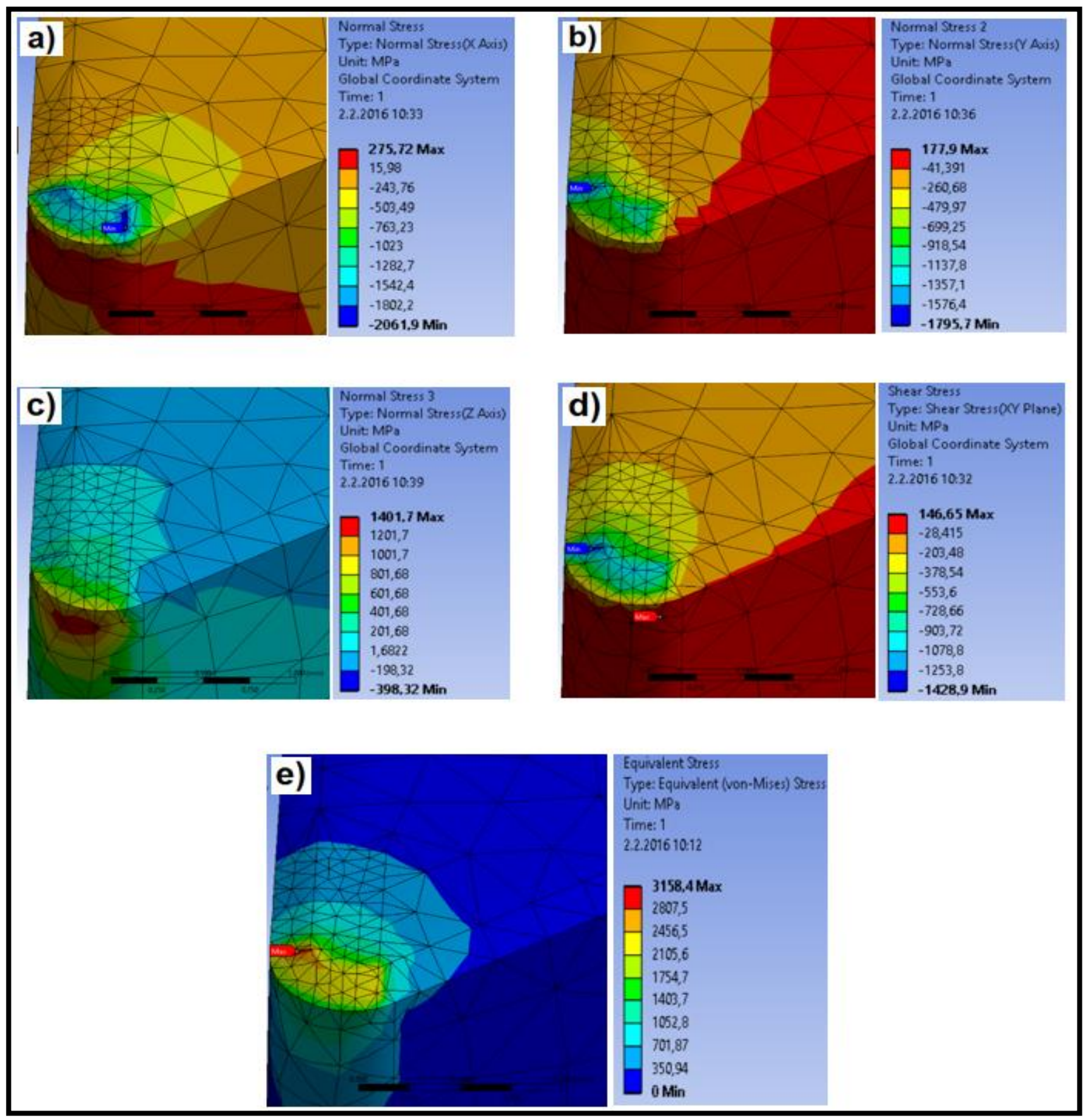

Fig. 5 Stress distributions: a) $\sigma_{x}$, b) $\sigma_{y}$, c) $\sigma_{z}$, d) $\tau_{x y}$, e) $\sigma_{e}(V=90 \mathrm{~m} / \mathrm{min}, a=0.3 \mathrm{~mm}, f=0.15 \mathrm{~mm} / \mathrm{rev})$ 


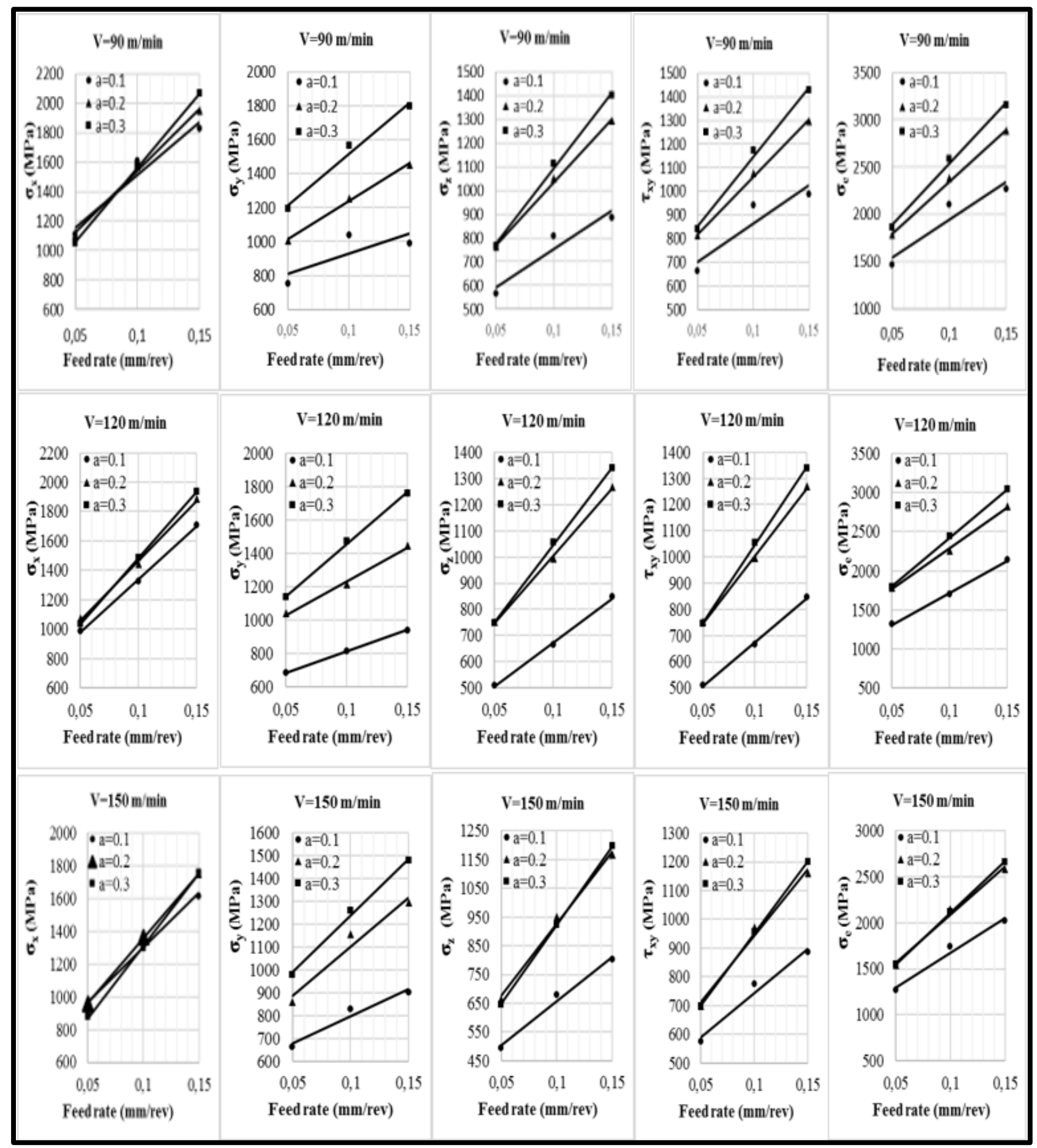

Fig. 6 Cutting tool stresses versus cutting parameters

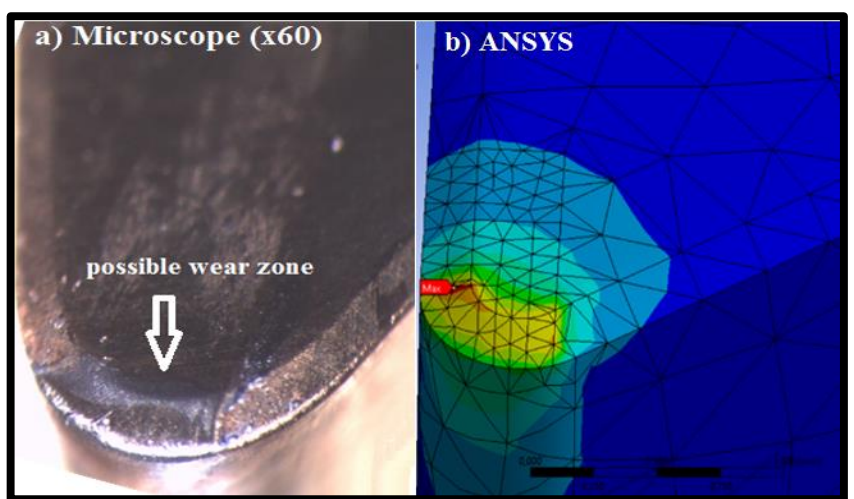

Fig. 7 Cutting tool images $(V=90 \mathrm{~m} / \mathrm{min}, f=0.15 \mathrm{~mm} / \mathrm{rev}$, $a=0.3 \mathrm{~mm}$ )
In hard turning, crater wear and flank wear are frequently appeared wear types owing to diffusion and abrasion wear mechanisms as can be seen in Ref [11]. These wear types were not detected on uncoated ceramic inserts while some scratches may occur on it during hard turning in this study (Fig. 7, a). Because, hard turning experiments have been performed in short length of workpiece. However, von Mises stress distributions in cutting tool rake face provide information about probable tool wear zone occurred at the tip of tool-chip contact area once hard turning has been continued (Fig. 7, b), as mentioned in Ref. [16]. In addition, the crater wear may appear at the chamfered zone of insert nose in hard turning because of the very small cutting 
area consisting of depth of cut and feed rate. Because, chamfered tool geometry causes increase of negative rake angle and thereby cutting forces, thus high cutting tool stresses occurred on tool-chip contact area. As seen from Fig. 5, d, shear stresses in xy-plane $\left(\tau_{x y}\right)$ may also affect the crater wear. Because xy-plane involves the tool-chip contact area of ceramic insert. On the other hand, flank wear is strongly affected with depth of cut [22]. The normal compressive stresses in z-direction $\left(\sigma_{z}\right)$ increase by increasing feed force as increasing depth of cut significantly affect the feed force (Table 2). Also, tool stresses in x-direction $\left(\sigma_{x}\right)$ has been affected by exerted pressure of squeezed material which is formed small depth of cut in hard turning. Thus, this wear type occurred on the flank face may be significantly affected from $\sigma_{z}$ and then $\sigma_{x}$.

As can be seen from the Fig. 7, cutting tool image taken from ANSYS and tool microscope are very similar. This result shows that the model of tool-chip contact area and boundary conditions of applying cutting force components on this area is correct. Hence, it is possible to say that the prediction of cutting tool stresses by finite element analysis and so the type of tool wear can be determined in hard tuning processes.

\section{Conclusion}

In this study, cutting forces and cutting tool stresses have been investigated in hard machining of DIN 1.2344 tool steel workpieces with $55 \pm 1$ HRC hardness using uncoated ceramic inserts. Cutting tool stresses have also been analyzed with finite element method. The following conclusions are drawn from this study:

1. The cutting forces components $\left(F_{f}, F_{r}, F_{c}\right)$ increased by increasing feed rate and depth of cut. It was determined that cutting force values has a little change with cutting speed. It was shown that cutting speed has a little influence on feed force and radial force while it has insignificant effect on $F_{c}$ in these cutting conditions.

2. The most effective factor on feed force and main cutting force is depth of cut with $82.66 \%, 51.35 \%$, respectively and on radial forces is feed rate with $50.10 \%$ PCR according to ANOVA results.

3. All cutting tool stresses decreased by increasing cutting speed, but increased with increasing feed rate. The depth of cut has increasing effect on cutting tool stresses except of $\sigma_{x}$ which has no specific increase or decrease based on depth of cut due to probable tool vibration caused by squeezed material.

4. ANSYS results and tool image taken from microscope in order to locate the possible wear zone on cutting tool showed consistency. This situation revealed that the model of tool-chip contact area and boundary conditions for applying cutting force components on this area is correct.

\section{References}

1. Tonshoff, H.K.; Arend, C.; Amor, R.B. 2000. Cutting of hardened steel, CIRP Annals- Manufacturing Technologies 49(2): 547-566.

http://dx.doi.org/10.1016/S0007-8506(07)63455-6.
2. Hashimoto, F.; Guo, Y.B.; Warren, A.W. 2006. Surface integrity difference between hard turned and ground surfaces and its impact on fatigue life, CIRP AnnalsManufacturing Technologies 55 (1): 81-84. http://dx.doi.org/10.1016/S0007-8506(07)60371-0.

3. Huang, Y.; Chou, Y.K.; Liang, S.Y. 2007. CBN tool wear in hard turning: a survey on research progresses, International Journal of Advanced Manufacturing Technology 35: 443-453. http://dx.doi.org/10.1007/s00170-006-0737-6.

4. Meddour, I.; Yallese, M.A.; Khattabi R.; Elbah, M.; Boulanouar, L. 2015. Investigation and modeling of cutting forces and surface roughness when hard turning of AISI 52100 steel with mixed ceramic tool: cutting conditions optimization, International Journal of Advanced Manufacturing Technology 77: 1387-1399. http://dx.doi.org/10.1007/s00170-014-6559-z.

5. Bensouilah, H.; Aouici, H.; Meddour, I.; Yallese, M.A.; Mabrouki, T.; Girardin, F. 2016. Performance of coated and uncoated mixed ceramic tools in hard turning process, Measurement 82: 1-18. http://dx.doi.org/10.1016/j.measurement.2015.11.042.

6. Kumar, A.S.; Dural, R.; Somakunar, T. 2003. Мachinability of hardened steel using alumina based ceramic cutting tools, International Journal of Refractory Metals and Hard Materials 21: 109-117. http://dx.doi.org/10.1016/S0263-4368(03)00004-0.

7. Gaitonde, V.N.; Karnik, S.R.; Figueira, L.; Davim, J.P. 2009. Machinability investigations in hard turning of AISI D2 cold work tool steel. International Journal of Refractory Metals and Hard Materials 27: 754-763. http://dx.doi.org/10.1016/j.ijrmhm.2008.12.007.

8. Karpuschewski, B.; Schmidt, K.; Beň̌, J.; Maňkova, I.; Prilukova, J. 2014. Measuring procedures of cutting edge preparation when hard turning with coated ceramics tool inserts. Measurement 55: 627-640. http://dx.doi.org/10.1016/j.measurement.2014.06.008.

9. Sokovic, M.; Barisic, B.; Sladic, S. 2009. Model of quality management of hard coatings on ceramic cutting tools, Journal of Materials Processing Technology 209: 4207-4216. http://dx.doi.org/10.1016/j.jmatprotec.2008.11.026.

10. Bhattacharya, A.K.; Zimmermann, K.; Schneider, G.A.; Hintze, W. 2008. Influence of surface modification on the cutting performance of reaction-sintered $\mathrm{Al}_{2} \mathrm{O}_{3}$-TiOC ceramics, Journal of the American Ceramic Society 91 (9): 2982-2986. http://dx.doi.org/10.1111/j.1551-2916.2008.02559.x.

11. Aslantas, K.; Ucun, I.; Cicek. A. 2012. Tool life and wear mechanism of coated and uncoated $\mathrm{Al}_{2} \mathrm{O}_{3} / \mathrm{TiCN}$ mixed ceramic tools in turning hardened alloy steel. Wear 274-275: 442-451. http://dx.doi.org/10.1016/j.wear.2011.11.010.

12. Shalaby, M.A.; El Hakim, M.A.; Abdelhameed, M.M.; Krzanowski, J.E; Veldhuis, S.C.; Dosbaeva, G.K. 2014. Wear mechanisms of several cutting tool materials in hard turning of high carbon-chromium tool steel, Tribology International 70: 148-154. http://dx.doi.org/10.1016/j.triboint.2013.10.011.

13. Yan, H.; Hua, J.; Shivpuri, R. 2007. Flow stress of AISI H13 die steel in hard machining, Materials and Design 28 (1): 272-277. http://dx.doi.org/10.1016/j.matdes.2005.06.017. 
14. Umbrello, D.; Rizzutia, S.; Outeiro, J.C.; Shivpuri, R.; M'Saoubi, R. 2008. Hardness-based flow stress for numerical simulation of hard machining AISI H13 tool steel, Journal of Materials Processing Technology 199: (1-3) 64-73. http://dx.doi.org/10.1016/j.jmatprotec.2007.08.018.

15. Özel, T. 2009. Computational modelling of 3D turning: Influence of edge micro-geometry on forces, stresses, friction and tool wear in PcBN tooling, Journal of Materials Processing Technology 209 (11): 5167-5177. http://dx.doi.org/10.1016/j.jmatprotec.2009.03.002.

16. Kurt, A.; Yalçin, B.; Yilmaz, N. 2015. The cutting tool stresses in finish turning of hardened steel with mixed ceramic tool, International Journal of Advanced Manufacturing Technology 80: 315-325. http://dx.doi.org/10.1007/s00170-015-6927-3.

17. Zorev, N.N. 1963. Inter-relationship between shear processes occurring along tool face and shear plane in metal cutting, In International Research in Production Engineering, NewYork, Proceedings of the International Production Engineering Research Conference.

18. Toropov, A.; Ko, S.L. 2003. Prediction of tool-chip contact length using a new slip-line solution for orthogonal cutting, International Journal of Machine Tools and Manufacture 43: 1209-1215. http://dx.doi.org/10.1016/S0890-6955(03)00155-X.

19. Korkmaz, M.E. 2015. Modeling of Cutting Tool Stresses on Machining of Hardened Cold Work Tool Steel, M. Sc. Thesis, Graduate School of Natural and Applied Sciences, Karabük.

20. Yücel, E.; Günay, M. 2012. Modelling and optimization of the cutting conditions in hard turning of high-alloy white cast iron (Ni-Hard), Proceedings of the Institution of Mechanical Engineers, Part C: Journal of Mechanical Engineering Science 227 (10): 2280-2290. http://dx.doi.org/10.1177/0954406212471755.

21. Kurt, A. 2009. Modelling of the cutting tool stresses in machining of Inconel 718 using artificial neural networks, Expert Systems with Applications 36(6): 96459657.

http://dx.doi.org/10.1016/j.eswa.2008.12.054.
22. Varaprasad, B.; Srinivasa, R.C.; Vinay, P.V. 2014. Effect of machining parameters on tool wear in hard turning of AISI D3 steel, Procedia Engineering 97: 338345.

http://dx.doi.org/10.1016/j.proeng.2014.12.257.

\section{Günay, M. E. Korkmaz, N. Yaşar}

\section{FINITE ELEMENT MODELING OF TOOL STRESSES ON CERAMIC TOOLS IN HARD TURNING}

S u m m a r y

Hard turning process has been developed as a possible alternative instead of more expensive cylindrical grinding operations. This process involves many cutting conditions like traditional turning such as machining parameters, nose radius and tool geometry. This study aims that cutting force components $\left(F_{f}, F_{r}, F_{c}\right)$ and cutting tool stresses depending on cutting conditions which are cutting speed, depth of cut and feed rate have been investigated in hard turning of DIN 1.2344 tool steel using uncoated ceramic tools. The experiments of hard turning were performed based on full factorial design. The distributions of cutting tools stresses were analyzed based on finite element method by using ANSYS software. ANOVA results showed that the most important factor on all cutting force components is the depth of cut while cutting speed has insignificant effect. In the results of study, it is shown that cutting tool image taken from ANSYS via finite element analysis and tool microscope are very similar. It is possible to say that the boundary conditions for loading of cutting force components are correct and the prediction of cutting tool stresses by finite element analysis can be determined in hard tuning processes.

Keywords: Finite element method, cutting tool stress, hard turning, cutting force, ceramic tool.

Received March 11, 2016 Accepted June 08, 2017 